\title{
Economic Pressure, Livelihood Strategy, and Family Well-being in Cimanuk Watershed, Garut and Indramayu, West Java, Indonesia
}

\author{
Hamira Sabania* \\ Department of Family and Consumer Sciences, \\ Faculty of Human Ecology, \\ Bogor Agricultural University
}

\author{
Hartoyo \\ Department of Family and Consumer Sciences, \\ Faculty of Human Ecology, \\ Bogor Agricultural University
}

*Corresponding author: hamirasabania@gmail.com

\begin{abstract}
The objective of this study is to analyze economic pressure, livelihood strategy, and well-being of families in Cimanuk Watershed. This study used a cross-sectional study design. As many as 72 samples of lower middle class families determined by Poverty Line of BPS 2013 that have toddler and school age children were chosen puposively. This study was conducted in Garut District and Indramayu District. The results showed that inspite of being in poverty, only one out of three families felt highly economic pressure, and one out of ten families perceived poorly well-being. Family economic pressure was affected by the region difference, education level of father, and ownership of financial resources. Meanwhile, family well-being was affected by the education level of the father, financial resources, social resources, access to the environment, economic pressure, and livelihood diversification. Livelihood diversification is the strategy that most poor families did in Cimanuk Watershed. Livelihood diversification of families was affected by the age of the wife, expenditure per capita, social capital, and access to the environment.
\end{abstract}

Keywords: economic pressure, livelihood strategy, watershed, well-being

\begin{abstract}
Abstrak. Penelitian ini bertujuan untuk menganalisis tekanan ekonomi, strategi nafkah, dan kesejahteraan keluarga yang berada di Daerah Aliran Sungai (DAS) Cimanuk. Sebanyak 72 keluarga dari kalangan menengah ke bawah (ditentukan berdasarkan Garis Kemiskinan BPS 2013) yang mempunyai anak balita dan anak usia sekolah dipilih secara sengaja sebagai contoh penelitian. Penelitian dilakukan di Kabupaten Garut dan Kabupaten Indramayu, Jawa Barat. Hasil penelitian menunjukkan bahwa meskipun dalam keadaan miskin, hanya satu dari tiga keluarga yang merasa tekanan ekonominya tinggi, dan satu dari sepuluh keluarga yang merasa kesejahteraannya rendah. Tekanan ekonomi keluarga dipengaruhi oleh perbedaan wilayah, pendidikan kepala keluarga, dan kepemilikan modal finansial. Sementara itu, kesejahteraan keluarga dipengaruhi oleh pendidikan kepala keluarga, modal finansial, modal sosial, akses terhadap lingkungan, tekanan ekonomi, dan pola nafkah ganda. Pola nafkah ganda merupakan strategi nafkah yang paling banyak dilakukan keluarga miskin di DAS Cimanuk. Pola nafkah ganda yang dilakukan keluarga dipengaruhi oleh usia istri, pengeluaran per kapita, modal sosial, dan akses terhadap lingkungan.
\end{abstract}

Kata kunci: daerah aliran sungai, kesejahteraan, strategi nafkah, tekanan ekonomi 


\section{Introduction}

Poverty is one of the most common problems experienced by developing countries, including Indonesia. Indonesia is a country that is fertile and has abundant natural resources, but most people are poor (Wahyudi and Sismudjito, 2007). Poverty is multi-dimensional and multi-sectoral problems in which high poverty and economic pressure will increase the risk of insecurity in a family (Hartoyo, 2009). According to Widiyanto, Setyowati and Suwarto (2010), one approach to understanding poverty is sustainable livelihood. This approach discusses not only income and employment but also more holistic topics. Livelihood strategy is the effort made by the family in order to meet their needs. Livelihood strategies undertaken by the family to survive can be agricultural intensification-extensification, livelihood diversification, and migration (Scoones, 1998).

The success of the livelihood strategy undertaken by the family will be determined by livelihood resources owned by the family (Dharmawan, 2011). Livelihood assets or family resources consist of five aspects: financial capital, human capital, physical resources, social resources, and natural resources (FAO and ILO, 2009; Ellis, 2000; Frankenberger et al., 2002). The condition of natural resources and human resources will affect the way how families do their living strategy (Carswell, 1997; Ellis, 1999).

Studies and research on economic pressures, livelihood strategies, and family well-being have actually been conducted in Indonesia even worldwide. The study on economic pressures has mostly been conducted by Sunarti $(2005 ; 2009)$ and Elder et al. (1992; 1994; 1995). Meanwhile, the study on livelihood strategies has been carried out by Darmawan (2007), Scoones (1998; 2009), Farrington et al. (2002), and on well-being by Dienner $(1999 ; 2005)$. Although there have been many studies concerning those issues, the specific one on watershed area is still rarely performed. According to the Ministry of Environment, Cimanuk Watershed as one of the natural capitals is the main support for water resources in West Java. As the region is predominately dependent on agriculture, Cimanuk Watershed has an important role as a source of irrigation. Unfortunately, the fluctuation in the dry and rainy season makes the area around the river becomes prone to flooding when the rainy season and drought in the dry season. This condition is in line with the study of Sulaksana et al. (2013) which states that Cimanuk Watershed primarily on the upstream side of an area is prone to erosion. Unfavorable environmental conditions will affect the family economic pressures and livelihood strategies that ultimately impact the family well-being.

Cimanuk River is the second longest river in West Java that flows from Garut District (upstream) to Indramayu District (downstream) (Ministry of Environment, 2013). For Garut, Cimanuk River as a source of irrigation has a very important role for the sustainability of the local community because the majority of the population works in the agricultural sector (Lestari, 2012). Cimanuk River is expected to contribute to the economy of Garut District society so as to improve the ability of the local economy. Meanwhile, in contrast to Garut, in Indramayu District there are some flood-prone locations that need attention and further treatment. Floods occurred in Indramayu has made the havest of agricultural land and fishing ponds fail. Besides that, other impact is the emergence of various skin diseases and dengue fever (Ministry of Public Works, 2010). 
Based on these facts, there is a difference in the area that is predicted to affect the family life. Therefore, this study aimed to analyze the economic pressure, livelihood strategies, family well-being, and the factors that affect livelihood strategies and wellbeing in Cimanuk Watershed.

\section{Method}

\section{Participants}

This study was conducted in the upstream and downstream of Cimanuk River by choosing Simpang Village, Cikajang Subdistrict and Sukatani Village, Cisurupan Subdistrict as the representative of the upstream area (Garut District) while the downstream area (Indramayu District) was represented by Village Pilangsari, Jatibarang Subdistrict; Dukuh Village, Indramayu Subdistrict; and Kenanga Village, Sindang Subdistrict. The location was chosen purposively with the consideration of the closest villages to Cimanuk River and the usage of Cimanuk River as a natural capital. The sampling technique of each village was done purposively and the criterion was a family with toddlers and school-age children. The total sample from five villages was 142 families (upstream=71; downstream=71). Finally, as many as 72 families (upstream=40; downstream=32) were involved for further analysis after the screening process by the poverty line of Statistics Indonesia 2013.

\section{Measures}

Data were collected through a survey toward the wife as the respondents using a structured questionnaire, which included: (1) family characteristics (family size, age, length of study, occupation, and expenditure per capita); (2) the ownership of family resources (human resource, natural resource, social resource, physical resource, and financial resource); (3) family economic pressure; (4) the type of livelihood strategy; and (5) the perception of the family well-being.

Human resource and natural resource were measured using the instruments referring to the concept of Farrington, Ramasut, and Walker (2002), social resource using the modified instruments of Grootaert et al. (2003), financial resource refered to Moser (2005), Farrington, Ramasut, and Walker (2002), Belcher et al. (2012), Kamarrudin and Samsudin (2014), and physical resource refered to $\mathrm{Su}$ and Shang (2012). Family economic pressure was measured by families' perception (represented by housewives) of the economic difficulties experienced by families with a total of 10 valid questions and the reliability value of 0.792 . The questionnaire referred to the concept of Elder et al. (1992) and Elder et al. (1995), consisted of 4-point scale (never to very often) and obtained score ranged between 10 and 40 .

Livelihood strategy was measured referring to the concept of Scoones (1998) and Carswell (1967) with a total of 12 valid questions rated on a 4-point scale (never to very often), and the reliability value of 0.638 . The obtained score ranged between 21 and 84. The perception of family well-being, as represented by housewives, was measured using instruments developed by Puspitawati and Herawati (2008), as cited in Puspitawati (2012), which had been modified with 21 valid questions rated on a 4-point scale (strongly unsatisfied to strongly satisfied), and the reliability value of 0.826 . 
Obtained score from each main variable was transformed into index score and categorized into three categories (low, moderate, high) based on class interval or the spread of the data. This effort was aimed to better understand the analysis and data interpretation. The index and class interval formulas are as follow:

$$
\text { Index }=\frac{\text { actual score }- \text { minimum score }}{\text { maximum score }- \text { minimum score }} \times 100
$$

Where,

Index $\quad=$ value of $0-100$

Actual score $\quad=$ obtained score

Minimum score $\quad=$ the lowet score

Maximum score $\quad=$ the highest score

$$
\text { Class interval }(I)=\frac{\text { maximum score }(N T)-\text { mininum score }(N R)}{\text { number of class }}
$$

The category of family resource, economic pressure, livelihood strategies, and well-being is as follow: low: 0-33.33, medium: 33.34-66.67, high: 66.68-100.

\section{Analysis}

The data analysis consisted of descriptive and inferential analysis (multiple linear regression and independent sample t-test) using Microsoft Excel for Windows and SPSS 22.0 for Windows. Multiple linear regression analysis was conducted to analyze the factors affecting the family livelihood strategy and family well-being. Furthermore, the independent sample t-test was done to identify the difference between family characteristics, family resources, livelihood strategy, family economic pressure, and family well-being based on two different areas (upstream and downstream areas of Cimanuk River).

\section{Result}

\section{Family Characteristics}

The family as a sample in this study was a young-couple family with the average family size of 5 members. The average education level of the families was low (equivalent to elementary school). It was directly proportional to the average family expenditure per capita which was low as well. The result of t-test for equality of mean indicated that there were significant differences in family size, education level of husband and wife, and the average family expenditure per capita between two areas. The family size in the upstream area was bigger than that in the downstream area. Statistics Indonesia (2012) mentions that poor households tend to have more family members so that the increasing human resources are blocked.

Conversely, the education level and expenditure of families in downstream area were higher. The most dominant job of the husbands in Cimanuk Watershed was laborers, both farm and non farm laborers. It supports the surveyed by Statistics Indonesia (2008) that poverty is often attached to those working in the agricultural sector, such as small farmers, fishermen, farm laborers, as well as honey and timber seeker in the forest. In the upstream area, working as farmers and farm laborers was 
usually done by the families simultaneously. Meanwhile, non farm laborers were usually vegetable porters. In contrast to the upstream, the husband's job in downstream area was more diverse, although it remained being dominated by the laborers. Non farm labor jobs in downstream area were brick laborers, tofu factory laborers, and construction workers. However, during the harvest season many husbands usually did double jobs as seasonal farm laborers. Wives, on the other hand, were partially housewives and devoted their time to take care of the toddler. Puspitawati (2012) has mentioned that families with toddlers and school-age children had higher domestic job demands, thus the wife usually decided to stop working in the public sector. In the case of working wives, they usually asked the relatives or the oldest child for taking care of their child. Even in some families in the upstream area, working wives as laborers were used to take their children to the garden when working.

\section{Family Resources}

Family resources discussed in this study consisted of human resources (age, family size, and education), social resources, natural resouces, physical resources, and financial resources. The ownership of human resources (educational level), physical resources, and financial resources of the families in this study was generally low. The result of t-test for equality of mean showed that there were significant differences in human resources, financial resources, and natural resources in both upstream and downstream areas. In terms of education and financial resources, both were higher in the downstream area than those in the upstream area. On the other hand, the natural resources of families in upstream area were higher than those in downstream area. Furthermore, the ownership of social resources in both areas was categorized high whereas the physical and financial capitals were evenly moderate.

Natural resource is a natural resource used by the family to survive (Farrington, Ramasut, and Walker, 2002). The natural resources in this study refer to as the existence and utilization of Cimanuk River and forest. For the families in the upstream area, the river was utilized to irrigate their gardens whereas the families in the downstream area used water from Cimanuk River not only for irigatataion but also for making tofu and bricks. Meanwhile, more than half of the families in the upstream area used trees from the forest to cook as one of the strategies to cut their food expenses. In addition, the family also used the woods from forest to build the houses so that almost all houses of poor families were made from wood.

Financial resources in this study were seen from the ownership of cash, savings, social gathering, debt, insurance, and a source of emergency funds (Moser, 2005; Farrington, Ramasut, and Walker, 2002; Belcher et al., 2012). Moreover, financial resources are also counted from the family income (Kamarrudin and Samsudin, 2014). The result of this study showed that the families in the downstream area held higher debt than those in the upstream area. Furthermore, the ownership of savings, social gathering, and insurance is one of the families' assets that can be utilized in high economic pressure. The ownership of savings, social gathering, and family insurance in the downstream area was higher than that in the upstream area. In fact, none of the families in the upstream area had an insurance.

Physical resources are the fundamental infrastructures that can help families in terms of doing their livelihood strategy ( $\mathrm{Su}$ and Shang, 2012). The ownerships of physical resources in this study included the ownership of home, electronic equipment, 
jewelery, work equipment, and vehicle. The high physical resources in the upstream area were due to six of the seven poor families that already had houses.

\section{Family Economic Pressure}

Economic pressure is one of the components that affect the family well-being (Sunarti and Firdaus, 2009; Robila, 2006). The economic pressure of the families in this study refers to the perception of economic difficulties to meet the daily needs. In spite of coming from a poor family, the result showed that there was only one out of three families who perceived high economic pressure (Table 1). This may happen because although families in the study are categorized as poor families, they do not perceive any difficulties to meet the specific needs such as health and education because the government supports them. Although it was not statistically significant, the family in the upstream area felt economically pressure higher than that in the downstream area. However, further test was done on each item and there was a difference in the statement "difficulties in obtaining jobs". Family in the downstream area revealed that it was more difficult to find a job. Based on the in-depth interview, the respondents said that the upstream climate is very supportive for the majority of their jobs (farmers and farm laborers). Looking for job in this area is not a big deal. It does not require higher education, as long as one has the will and good body condition, he or she can work. Conversely, family in the downstream area does not haveva fixed job, and most of the time the husband will rely on the wife.

Table 1 Distribution of families by the economic pressure and areas

\begin{tabular}{lcccccc}
\hline \multirow{2}{*}{ Economic pressure } & \multicolumn{2}{c}{ Upstream } & \multicolumn{2}{c}{ Downstream } & \multicolumn{2}{c}{ Total } \\
\cline { 2 - 7 } & $\mathrm{n}$ & $\%$ & $\mathrm{n}$ & $\%$ & $\mathrm{n}$ & $\%$ \\
\hline Low $(<33.33)$ & 4 & 10.0 & 6 & 18.7 & 10 & 13.9 \\
Moderate $(33.34-66.67)$ & 22 & 55.0 & 12 & 37.5 & 36 & 50.0 \\
High $(66.68-100.00)$ & 14 & 35.0 & 14 & 43.8 & 26 & 36.1 \\
\hline Total & 40 & 100.0 & 32 & 100.0 & 72 & 100.0 \\
$P$ & \multicolumn{2}{c}{0.924} \\
\hline
\end{tabular}

Note. $\left(^{*}\right)$ significant at $p<0.1 ;\left(^{* * *}\right)$ significant at $p<0.05 ;\left(^{* * * *}\right)$ significant at $p<0.01$

\section{Family Livelihood Strategy}

Livelihood strategy is capabilities, assets, and resources owned by the family to meet basic living needs (Chambers and Conway, 1991). Scoones (1998) explains that the livelihood strategy undertaken by a family in order to survive can be either on-farm activities (including livestock, fisheries, and forestry), non-farm (outside agriculture sector), or a combination of both. Furthermore, livelihood strategies are divided into three types, namely agricultural intensification-extensification, livelihood diversification, and migration. Meanwhile, migration is the livelihood strategy by moving to other areas both permanently and temporarily.

Table 2 Types of livelihood strategies by areas

\begin{tabular}{lcccc}
\hline \multirow{2}{*}{ Livelihood strategy } & Upstream & Downstream & Total & \multirow{2}{*}{$p$} \\
\cline { 2 - 4 } & Mean \pm SD & Mean \pm SD & Mean \pm SD & \\
\hline Agricultural intensification-extensification & $22.5 \pm 22.6$ & $24.8 \pm 20.8$ & $23.5 \pm 21.7$ & 0.659 \\
Livelihood diversification & $34.4 \pm 31.5$ & $45.1 \pm 30.5$ & $39.2 \pm 31.3$ & 0.151 \\
Migration & $5.8 \pm 11.5$ & $12.5 \pm 15.7$ & $8.8 \pm 13.8$ & $0.049^{* *}$ \\
\hline Note. $\left(^{*}\right)$ significant at $p<0.1 ;\left(^{* *}\right)$ significant at $p<0.05 ;\left(^{* * * *}\right)$ significant at $p<0.01$ & &
\end{tabular}

Note. $\left(^{*}\right)$ significant at $p<0.1 ;\left({ }^{* * *}\right)$ significant at $p<0.05 ;\left({ }^{* * * * *}\right)$ significant at $p<0.01$ 
The results showed that the livelihood diversification was mostly done by the families in both areas (Table 2). Families striving to utilize all human resources existed at family (wife and children) to do multiple jobs. Besides famers, they also became farm laborers, vegetable porters, and construction workers. Meanwhile, the other types of livelihood strategies, agricultural intensification-extensification and migration were included in the low category.

Table 3 shows the results of multiple linear regression analysis of factors that predict each type of livelihood strategies. Variables in the model predict the agricultural intensification-extensification, livelihood diversification, and migration respectively amounting to 20.9 percent, 24.5 percent, and 24.1 percent while the rest was predicted by other factors. The results implied that highly economic pressure and social resources will more encourage family to apply more agricultural intensification-extensification strategy. Financial resources had a negative significant influence on the strategy of agricultural intensification-extensification, indicating that family with low financial resources will be more likely to apply this livelihood strategy.

The age of wife, social resources, and access to the environment were proved to influence positively on livelihood diversification. This means that the older the wife, the higher possibility of the families to undertake livelihood diversification in order to achieve prosperity. The same thing went to the higher the social resources and the more supportive environmental conditions. The supportive environmental conditions would enable the families to undertake livelihood diversification. Migration was predicted by age of husband and wife. As in livelihood diversification, along with getting older of the husband, the migration got lower as well. High ownership of physical and natural resources will be more likely to lead family to do migration.

Table 3 The results of multiple linear regression analysis of the factors predicting livelihood strategy

\begin{tabular}{|c|c|c|c|c|c|c|}
\hline \multirow[t]{2}{*}{ Variable } & \multicolumn{2}{|c|}{$\begin{array}{c}\text { Agricultural } \\
\text { intensification- } \\
\text { extensification }\end{array}$} & \multicolumn{2}{|c|}{$\begin{array}{l}\text { Livelihood } \\
\text { diversification }\end{array}$} & \multicolumn{2}{|c|}{ Migration } \\
\hline & $\mathrm{B}$ & Sig. & $\mathrm{B}$ & Sig & $\mathrm{B}$ & Sig. \\
\hline Constant & -60.899 & $0.024^{* * *}$ & -100.629 & $0.009^{* * *}$ & -12.873 & 0.436 \\
\hline $\begin{array}{l}\text { Region }(0=\text { upstream, } \\
1=\text { downstream })\end{array}$ & -7.828 & 0.322 & -16.574 & 0.139 & -11.415 & $\mathbf{0 . 0 2 3}^{* *}$ \\
\hline $\begin{array}{l}\text { Education level of husband } \\
\text { (year) }\end{array}$ & 1.079 & 0.336 & -0.858 & 0.587 & -0.682 & 0.331 \\
\hline $\begin{array}{l}\text { Education level of wife } \\
\text { (year) }\end{array}$ & 0.573 & 0.664 & -0.011 & 0.995 & 1.084 & 0.191 \\
\hline Age of husband (year) & -0.504 & 0.292 & -0.389 & 0.563 & -0.650 & $0.032^{* *}$ \\
\hline Age of wife (year) & 0.645 & 0.319 & 1.922 & $0.038^{* *}$ & 1.239 & $0.003^{* * * *}$ \\
\hline Family size (person) & 2.140 & 0.323 & 2.016 & 0.509 & 0.976 & 0.470 \\
\hline Physical resources & 0.230 & 0.137 & 0.161 & 0.455 & -0.239 & 0.015 *** \\
\hline Expenditure & $-3.420 \times 10^{-6}$ & 0.544 & $-1.80 \times 10^{-5}$ & $0.026^{* *}$ & $-2.012 \times 10^{-7}$ & 0.954 \\
\hline Financial resources & -0.262 & $0.081^{*}$ & 0.105 & 0.615 & 0.121 & 0.192 \\
\hline Natural resources & 0.083 & 0.491 & 0.132 & 0.436 & 0.206 & $0.008^{* * * *}$ \\
\hline Social resources & 0.315 & $0.043^{* * *}$ & 0.403 & $0.066^{*}$ & -0.115 & 0.234 \\
\hline Economic pressure & 0.240 & $0.067^{*}$ & 0.225 & 0.217 & -0.064 & 0.427 \\
\hline Environmental condition & 0.470 & 0.086 & 1.008 & $0.010^{* *}$ & 0.113 & 0.506 \\
\hline $\mathrm{F}$ & \multicolumn{2}{|c|}{2.446} & & 2.769 & & 2.370 \\
\hline $\mathrm{R}$ square & \multicolumn{2}{|c|}{0.354} & & 0.383 & & 0.380 \\
\hline Adj R square & \multirow{2}{*}{\multicolumn{2}{|c|}{0.209}} & & 0.245 & & 0.241 \\
\hline Sig. & & 0.010 & & 0.004 & & 0.004 \\
\hline
\end{tabular}

Note. $\left(^{*}\right)$ significant at $p<0.1 ;\left({ }^{* *}\right)$ significant at $p<0.05 ;\left({ }^{* * * *}\right)$ significant at $p<0.01$ 


\section{Family Well-being}

Chambers (1995) defined prosperity as a good quality of life experience. Wellbeing/happiness/life satisfaction in this study was determined by assessing the wives' perception of the economic, physical, social, and psychological conditions (Table 5). This study found that families' perception of the economic well-being was in the lowest rank among other aspects while the highest rank was the physical aspect. In terms of economic and physical, family well-being level in downstream area was higher than that in the upstream area. On the other hand, the average score of the psychological and social aspects of the families in the upstream area was higher as how the wives responded on the items such as the relationship with parents and/or parents in law, relatives, and neighbours, and their happiness in general.

Table 4 Family well-being by the area

\begin{tabular}{lcccc}
\hline \multirow{2}{*}{ Well-being } & Upstream & Downstream & Total & \multirow{2}{*}{$p$} \\
\cline { 2 - 4 } & Mean \pm SD & Mean \pm SD & Mean \pm SD & 0.255 \\
Economic & $45.00 \pm 26.95$ & $52.43 \pm 27.69$ & $48.30 \pm 27.34$ & 0.229 \\
Physical & $65.00 \pm 36.94$ & $75.00 \pm 31.68$ & $69.44 \pm 34.83$ & 0.906 \\
Psychology & $60.93 \pm 17.41$ & $60.42 \pm 18.94$ & $60.70 \pm 17.98$ & 0.405 \\
Social & $63.19 \pm 11.30$ & $60.94 \pm 11.42$ & $62.19 \pm 11.33$ & 0.458 \\
\hline Total & $50.81 \pm 13.25$ & $52.95 \pm 10.47$ & $51.76 \pm 12.06$ & 0.4 \\
\hline
\end{tabular}

Note. $\left(^{*}\right)$ significant at $p<0.1 ;\left(^{* *}\right)$ significant at $p<0.05 ;\left({ }^{* * *}\right)$ significant at $p<0.01$

Table 5 The results of multiple linear regression analysis of the factors predicting family well-being

\begin{tabular}{|c|c|c|c|c|}
\hline \multirow{2}{*}{ Variable } & \multicolumn{2}{|c|}{ Unstandardized coefficient } & \multirow{2}{*}{$\frac{\text { Standardized coefficient }}{\text { Beta }}$} & \multirow[b]{2}{*}{$p$} \\
\hline & $\mathrm{B}$ & Error & & \\
\hline Constant & 65.470 & 19.056 & & $0.001^{* * * *}$ \\
\hline $\begin{array}{l}\text { Region }(0=\text { upstream, } \\
1=\text { downstream })\end{array}$ & -1.668 & 5.515 & -0.053 & 0.763 \\
\hline $\begin{array}{l}\text { Education level of husband } \\
\text { (year) }\end{array}$ & 1.612 & 0.754 & 0.289 & $0.037^{* *}$ \\
\hline $\begin{array}{l}\text { Education level of wife } \\
\text { (year) }\end{array}$ & -1.258 & 0.889 & -0.176 & 0.163 \\
\hline Age of husband (year) & -0.248 & 0.331 & -0.112 & 0.457 \\
\hline Age of wife (year) & 0.488 & 0.467 & 0.173 & 0.301 \\
\hline Family size (person) & -1.542 & 1.449 & -0.140 & 0.292 \\
\hline Physical resources & 0.136 & 0.110 & 0.150 & 0.221 \\
\hline Expenditure & $-2.463 \times 10^{-6}$ & 0.000 & -0.078 & 0.531 \\
\hline Financial resources & 0.243 & 0.102 & 0.309 & $\mathbf{0 . 0 2 1}^{\text {*3* }}$ \\
\hline Natural resources & 0.004 & 0.085 & 0.008 & 0.960 \\
\hline Social resources & 0.388 & 0.110 & 0.398 & 0.001 **** \\
\hline Environmental condition & -0.410 & 0.192 & -0.289 & $\mathbf{0 . 0 3 7}^{* *}$ \\
\hline Economic pressure & -0.211 & 0.089 & -0.293 & $\mathbf{0 . 0 2 2}^{* *}$ \\
\hline $\begin{array}{l}\text { Agricultural intensification- } \\
\text { extensification }\end{array}$ & 0.006 & 0.148 & 0.005 & 0.970 \\
\hline Livelihood diversification & -0.123 & 0.066 & -0.246 & $0.070^{*}$ \\
\hline Migration & 0.078 & 0.089 & 0.108 & 0.386 \\
\hline $\mathrm{F}$ & & & & 3.146 \\
\hline $\mathrm{R}$ square & & & & 0.478 \\
\hline Adj R square & & & & 0.326 \\
\hline Sig. & & & & 0.001 \\
\hline
\end{tabular}


As shown in Table 5, there are variables proved to predict significantly family well-being including education level of husband, financial resources, environmental condition, economic pressure, and livelihood diversification. The suggested model contributed to the family well-being as big as 32.6 percent while the rest of 67.4 percent was predicted by other factors that were not studied here. The findings indicate that highly economic pressures and efforts undertaken for livelihood diversification will predict the decreasing family well-being. Meanwhile, family with highly number of social resources, of financial resources, and highly level of education level of the husband will be more likely to have highly well-being as well.

\section{Discussion}

Jordan's (1996), as cited in Robila (2006), states that the vulnerability occurs when individual has the low capacity of natural and human resources. Human resources consist of skills, knowledge, and ability of individual to work (Farrington, Ramasut, and Walker, 2002). The study was conducted in rural areas and the results indicated the lack of education of the families, which was equivalent to elementary school. The results of previous survey conducted by Statistics Indonesia (2012) suggest that the education of poor families in rural areas is lower than that of poor families in urban areas. Hence, it leads family members to low expertise and knowledge that their productivity is low as well. The results are in line with the study of Hartayo, Djamaludin, and Herawati (2013) which stated that poor families tended to have unstable income. Indeed, unstable job will result in low incomes and bring economic pressure (Elder et al., 1992). Economic pressure as of components proved to predict family well-being, varied between the upstream and downstream areas of Cimanuk River. Upstream family perceived more pressures economically compared to the downstream family. Iskandar et al. (2006) has previously mentioned that one of the factors influencing perceived well-being is residence.

The study examined three types of livelihood strategy: agricultural intensification-extensification, livelihood diversification, and migration. In general, livelihood strategies done by family in the study were categorized poor. It is in accordance with the study of Kamarrudin and Samsudin (2014) showing that families with incomes below the poverty line obtained low scores in terms of livelihood strategies. Mooser (2005) has also suggested that livelihood strategies were associated with the vulnerability and lack of assets owned by the family.

The strategy of agricultural intensification-extensification of the family included diversifying the primary income sources (used intercropping systems for farmers), borrowing capital, expanding the area for farming, adding workers, increasing hours of work, and using modern technology such as tractor. However, the application of those strategies will depend on environmental conditions and natural resources (Carswell, 1997).

Livelihood diversification is done by employing all family members or having more than one job. This type of livelihood strategies is mostly undertaken by family in Cimanuk Watershed. There is a difference between livelihood diversification undertaken by poor families and non poor families (Widodo, 2011). Livelihood diversification undertaken by non poor families aims to expand their business and bring to higher level. Conversely, poor families do livelihood strategy as an effort to survive 
for living and release poverty. Age of wife, social resources, and access to environment were factors that may predict livelihood diversification. As Darmawan (2007) said that social and ecological systems would affect families' access to resources. Therefore, livelihood strategy will depend on socio-ecological changes of the environment.

On the other hand, Ellis $(1999 ; 2000)$ said that livelihood diversification is closely related to human resources and social relationships of the family. Although it was not significant, the results showed the association between age of husband and livelihood diversification. It is assumed that along the time, there will be health declines, thus it will be more difficult for the husband to do a lot of work. However, the opposite result occurred on the age of wife which was proved to influence positively on livelihood diversification. The implementation of livelihood diversification strategy is not separated from the women's roles. In fact, all women in this study had toddler so that there were obstacles for the wives to allocate their time for work. For working wives, they usually left the toddler with the oldest son, so that they could work as usual. In the case of large family size of less than or equal to 4 people, wives usually decide to stop working and take care of the child.

The results of in-depth interview in the upstream area showed that the farmers/farm laborer families undertook the livelihood diversification either by hiring all family members or by having a second job. In addition to working on their own land and becoming farm laborers in high economic pressure, they often became porters to generate more income. This is done mainly by the families that had a motor vehicle or good physical health. This phenomenon is consistent with the study of Saragih et al. (2007), that is, in order to meet their daily needs, farmer families in rural areas usually had a variety of activities and sources of income. Meanwhile, the livelihood diversification in the downstream area was usually done by the wives who helped their husband to be a trader as well. In the case of family with laborers as the main livelihood, in highly economic pressure the husbands switched their jobs to become motorcycle drivers or unemployed and dependent on his wife and children.

The low expenditure per capita suggests that families are still not economically prosperous. Scoones (2009) stated that the prosperity and sustainability of living is one of the ultimate goals of livelihood strategy, so that families with a lower level of wellbeing will make every effort to get out of poverty and become more prosperous. Low expenditure per capita also indicates that a family does not achieve economic prosperity yet. Furthermore, Ellis (2000) reveals 6 factors that affect the family to do livelihood diversification, including season, the risk of the strategy, labor market, credit market failures, asset strategies, and coping behaviors. Coping behavior is a form of anticipation when livelihood strategies fail. When the dry season (upstream) or during floods (downstream), the families usually look for another job that does not depend on natural conditions, for example by migrating either permanently or temporarily.

The results related to the factors that influenced the migration strategy found that the area differences, age of the husband and wife, financial resources, and natural resources influenced this strategy. The previous study conducted by Sunarti and Firdaus (2009) also found that the higher the husband's age, the fewer coping mechanisms done by the family. Conversely, the more mature the wife, the more family did migration strategy. Meanwhile, natural resources influenced positively on the migration strategy. This is in line with the study of Su and Shang (2012) who found that natural resources affected the livelihood strategies in general, while the other four capitals depended on the type of livelihood strategies undertaken. Financial resources had negative effect, 
indicating that the low ownership of financial resources will increase the migration strategy of the family.

Family well-being is one of the goals in undertaking livelihood strategy (Department For International Development, 1999). There were several factors that predicted family well-being in the study, such as, the education level of husband and financial resources. Dienner et al. (1999) found the association between the education level and perceived well-being of poor families. Hartoyo, Djamaludin, dan Herawati (2013) have also revealed that education will determine the occupation of the head of the household, in which it can increase the income. Thus, it leads a family to prosperity.

Besides education and financial resources, economic pressure has also negative influence on well-being. Poor families tend to have high number of member in which highly economic pressure will decrease family well-being (Sunarti dan Firdaus, 2009) and life satisfaction (Robila, 2006). Social reources had a positive influence on family well-being. This finding is in line with the study of Pramudita (2014) on rural and urban families. Furthermore, as the output of well-being, highly livelihood diversification will lower family well-being. Conversely, the rest livelihood strategies influenced positively on family well-being.

Data came from wives, thus well-being of the family cannot be separated from the wives' condition. Most of the time working wives are exhausted for doing double jobs in dometic and public sectors. This condition may cause more pressures and dissatisfaction. Besides, environmental condition will influence well-being. Chamber dan Conways (1991) mentioned that livelihood strategies have positive and negative effects on environment. It will increase the productivity of the natural resources. On the other hand, it will increase the natural damage, such as, deforestation and erosion.

Based on the results in both regions, there are differences in the characteristics of the family and resources owned by the family. It causes the difference in the use of family resources to make a living strategy. But in general there is no significant difference in the economic pressure, livelihood strategies, and family well-being in both regions. This is presumably because the family in both regions derived from similar demographic characteristics - the lower middle class family. In addition, Dienner et al. (2005) states that well-being is not solely influenced by environmental conditions but also by personality disposition.

\section{Conclusion and Recommendation}

\section{Conclusion}

The results show that there are differences in family resources ownership, particularly on human resources, financial resources, and natural resources. The ownership of families' human resources in the downstream area (Indramayu Subdictrict) is higher than that in the upstream area (Garut Subdictrict), especially in terms of education. The ownership of families' natural resources in the upstream area (Garut Subdictrict) is higher than that in the downstream area (Indramayu Subdictrict). There are significant differences of resources ownership between the two areas, but no significant difference of economic pressure, livelihood strategies, and family wellbeing. Inspite of being in poverty, there is only one out of three families perceiving highly economic pressure, and one out of ten families perceiving poor well-being. Livelihood diversification is mostly undertaken by poor families in Cimanuk 
Watershed. Livelihood diversification is predicted by the age of the wife, expenditure per capita, social resources, and access to the environment. Furthermore, agricultural intensification-extensification is predicted by the financial and social resources, and economic pressures while migration strategy is predicted by the area differences, age of husband and wife, physical and natural resources.

\section{Recommendation}

Cimanuk River has a very important role for the sustainability of family income. Therefore, it is necessary to pay more attention to the environmental sustainability in the basin in order to continue providing benefits for family life. This study has limitations in several aspects, such as, in the purposive sampling method in which the results can not represent the population as a whole. Furthermore, physical and financial resources are only measuresd from the aspect of perceived ownership instead of the exact quantity and/or quality of the resources. Future studies are expected to improve the limitations of this study.

\section{Reference}

Belcher, B., Bastide, F., Castella, J. C., \& Boissiere, M. (2012). Development of a village-level livelihood monitoring tool: A case-study in Viengkham District, Lao PDR. International Forestry Review, 14(4).

Carswell, G. (1997). Agricultural intensification and rural sustainable livelihoods: A 'think piece' (Working Paper 64). Retrieved from https://www.ids.ac.uk/files/dmfile/Wp64.pdf.

Chambers, R., \& Conway, G. R. (1991). Sustainable rural livelihoods: Practical concepts for 21st century. IDS Discusions paper 296. Retrieved from https://www.ids.ac.uk/files/Dp296.pdf.

Chambers, R. (1995). Poverty and livelihoods: Whose reality counts?. Environment and Urbanization, 7(1), 173-204. doi: 10.1177/095624789500700106.

Department for International Development. (1999). Sustainable livelihoods guidance sheet.

Retrieved from http://www.eldis.org/vfile/upload/1/document/0901/section2.pdf.

Dharmawan, A. H. (2007). Sistem penghidupan dan nafkah pedesaan: Pandangan sosiologi nafkah (livelihood sociology) mazhab Barat dan mazhab Bogor [Livelihood and rural livelihood systems: Livelihood sociology of Western ideology and Bogor ideology]. Sodality: Jurnal Transdisiplin Sosiologi, Komunikasi, dan Ekologi Manusia, 1(2), 169-192. Retrieved from http://journal.ipb.ac.id/index.php/sodality/article/view/5932/4609.

Elder, G. H., Jr., Conger, R. D., Foster, E. M., \& Ardelt, M. (1992). Family under economic pressure. Journal of Family Issues, 3(1), 5-37. doi: 10.1177/019251392013001002

Elder, G. H., Jr., Eccles, J. S., Ardelt, M., \& Lord, S. (1995). Inner-city parents under economic pressure: Perspectives on the strategies of parenting. Journal of Marriage and the Family, 57, 771-784.

Ellis, F. (1999). Rural livelihood diversity in developing countries: Evidence and policy implications. Journal London Overseas Development Institute. 
Ellis, F. (2000). The determinants of rural livelihood diversification in developing countries. Journal of Agricultural Economic, 51(2), 289-302. doi: 10.1111/j.14779552.2000.tb01229.x.

Farrington, J., Ramasut, T., \& Walker, J. (2002). Sustainable livelihood approaches in urban areas (Working Paper No. 162). Retrieved from http://www.odi.org/sites/odi.org.uk/files/odi-assets/publications-opinionfiles/2706.pdf.

Food and Agriculture Organization of the United Nations, \& International Labour Organization. (2009). The Livelihood Assessment Tool-Kit: Analysing and Responding to the Impact of Disasters on the Livelihoods of People (1st ed.). Roma \& Geneva: Authors.

Frankenberger, T. R., Luther, K., Becht, J., \& Katherine. (2002). Household Livelihood Security Assessments: A Toolkit for Practitioners. Tucson, AZ: Tango International, Inc.

Hartoyo. (2009). Pemberdayaan Ekonomi Keluarga Dalam Rangka Peningkatan Ketahanan Keluarga (Families Economic Empowerment in the Context of Family Resilience Enhancement). In E. Sunarti (Ed.), Naskah Akademis Pengembangan Model Ecovillage: Pengembangan Kawasan Pedesaan serta Peningkatan Sumbangan Pertanian dalam Peningkatan Kualitas Hidup Penduduk Pedesaan (Academic Development Model Ecovillage: Rural Area Development and Improvement of Agriculture's Contribution in the Life Quality Improvement of Rural Population) (pp. 207-233). Bogor, Indonesia: Lembaga Penelitian dan Pengabdian kepada Masyarakat (LPPM IPB).

Hartoyo, Djamaludin, M. D., \& Herawati, T. (2013). Transfer kemiskinan antar generasi di wilayah agroekologi yang berbeda: perdesaan dan perkotaan. Prosiding Seminar Hasil-Hasil PPM IPB 2013. 22, 682-697.

Ihsannudin, \& Wijayanti, L. (2013). Strategi peningkatan kesejahteraan masyarakat nelayan Kecamatan Pademawu Kabupaten Pamekasan (The strategy for improving the welfare of fishermen at Pademawu Sub-District, Pamekasan Regency). Jurnal Agriekonomika, 2(2), 149-189. Retrieved from http://journal.trunojoyo.ac.id/agriekonomika/article/view/433/404.

Iskandar, Hartoyo, Sumarwan, U., \& Khomsan, A. (2006). Faktor faktor yang mempengaruhi kesejahteraan keluarga (Factors that affect family well-being). Hasil Penelitian, 133-141. Retrieved from http://repository.usu.ac.id/bitstream/123456789/18931/1/ikm-des200610\%20(9).pdf.

Kamarrudin, R., \& Samsudin, S. (2014). The sustainable livelihoods index: A tool to assess the ability and preparedness of the rural poor in receiving entrepreneurial project. Journal of Social Economic Research, 1(6), 108-117.

Ministry of Environment. DAS Cimanuk [Cimanuk Watershed]. Retrieved from http://ppejawa.com/ekoregion/das-cimanuk/.

Ministry of Public Works. (2010). Pengelolaan Sumber Daya Air Sungai CimanukCisanggarung [Water resource management in Cimanuk River-Cisanggarung]. Jakarta, Indonesia: Author.

Lestari, D. V. (2012). Dinamika pembangunan masyarakat Kabupaten Garut 1993-2008 [The dynamics of community development Garut 1993-2008]. Student E-Journals Universitas Padjajaran, 1(1). Retrieved from http://jurnal.unpad.ac.id/ejournal/article/view/1755/1771. 
Moser, C. (2005). Asset, Livelihoods and Social Policy, Arusha Conference, "New Frontiers of Social Policy", Arusha, December 12-15.

Puspitawati, H. (2012). Gender dan Keluarga: Konsep dan Realita di Indonesia [Gender and Family: Concept and Reality in Indonesia]. Bogor, Indonesia: IPB Press.

Puspitawati, H., \& Herawati. (2013). Metode Penelitian Keluarga [Family Research Method]. Bogor, Indonesia: IPB Press.

Robila, M. (2006). Economic pressure and social exclusion in Europe. The Social Science Journal, 43(1), 85-97. doi:10.1016/j.soscij.2005.12.009.

Saragih, Lassa, J., \& Ramli, A. (2007). Sustainable livelihood framework. Retrieved from http://www.zef.de/module/register/media/2390_SL-Chapter1.pdf.

Scoones, I. (1998). Sustainable rural livelihoods: A framework for analysis (Working Paper 72). Retrieved from http://www.ids.ac.uk/publication/sustainable-rurallivelihoods-a-framework-for-analysis.

Scoones, I. (2009). Livelihoods perspectives and rural development. Journal of Peasant Studies, 36(1), 171-196. doi: 10.1080/03066150902820503.

Statistics Indonesia. (2008). Analisis dan Penghitungan Tingkat Kemiskinan 2008 [Analysis and Calculation of Poverty Level in 2008]. Jakarta, Indonesia: Author.

Statistics Indonesia. (2012). Analisis Data Kemiskinan Berdasarkan Data Pendataan Program Perlindungan Sosial (PPLS) 2011 [Poverty Data Analysis Based on Data Collection of Data Social Protection Program 2011]. Jakarta, Indonesia: Author.

Su, F., \& Shang, H. (2012). Relationship analysis between livelihood assets and livelihood strategies: A Heihe River Basin example. Sciences in Cold and Arid Regions, 4(3), 0265-0274. doi: 10.3724/SP.J.1226.2012.00265.

Sulaksana, N., Sukiyah, E., Sjafrudin, A., \& Haryanto, E. T. (2013). Karakteristik geomorfologi DAS Cimanuk bagian hulu dan implikasinya terhadap intensitas erosi serta pendangkalan Waduk Jatigede (Cimanuk Watershed geomorphological characteristics of the upstream and the implications for the intensity of erosion and silting Jatigede). Bionatura Jurnal Ilmu- ilmu Hayati dan Fisik, 15(2), 100-106. Retrieved from http://jurnal.unpad.ac.id/bionatura/article/view/7203.

Sunarti, E., \& Firdaus, M. (2009). Hubungan antara tekanan ekonomi dan mekanisme koping dengan kesejahteraan keluarga wanita pemetik teh (The relationship between economic stress and coping mechanisms with family well-being of women tea pickers). Jurnal Ilmu Keluarga dan Konsumen, 2(1), 21-31.

Sunarti, E., Tati, Atat, S. N., Noorhaisma, R., \& Lembayung, D. P. (2005). Pengaruh tekanan ekonomi keluarga, dukungan sosial, kualitas perkawinan, pengasuhan, dan kecerdasan emosi anak terhadap prestasi belajar anak (Influence of family economic pressure, social support, quality of marriage, parenting, and child emotional intelligence on child academic achievement). Media Gizi \& Keluarga, 29(1), 34-40.

Wahyudi, H., \& Sismudjito. (2007). Strategi adaptasi sosial ekonomi keluarga miskin pasca kenaikan harga bahan bakar minyak (BBM) (Socioeconomic adaptation strategies of poor families after the increase in fuel prices). Jurnal Harmoni Sosial, 1(2), 83-95. Retrieved from http://repository.usu.ac.id/bitstream/123456789/18583/1/har-jan2007-1\%20(1).pdf.

Widiyanto, Setyowati, R., \& Suwarto. (2010). Dinamika nafkah rumah tangga petani pedesaan dengan pendekatan sustainable livelihood approach (SLA) (The dynamics of rural farmers household income with sustainable livelihood approach). Jurnal Agritext. No 28. 
Widodo, S. (2011). Strategi nafkah berkelanjutan bagi rumah tangga miskin di daerah Pesisir. Makara, Sosial Humaniora, 15(1), 10-20. 